\title{
Comparison of the weight gain and the composition of blood and saliva in sheep grazing timothy and ryegrass swards
}

\author{
BY K. B. SINCLAIR \\ Animal Health Research Unit \\ AND D. I. H. JONES
}

Welsh Plant Breeding Station, University College of Wales, Aberystwyth

(Received 29 Fanuary 1968-Accepted 12 Fune 1968)

\begin{abstract}
I. After a preliminary period of 2 weeks indoor feeding on hay, two groups of wethers grazed either a timothy pasture or a ryegrass-dominant pasture for 12 weeks. The timothy was particularly low in sodium and chlorine.

2. Within a week of turning out, saliva sodium fell and potassium increased in the timothy group, and by the end of the experiment, the sodium: potassium ratio was $I \cdot 9: 1$. The changes in saliva were not reflected in blood composition. The rate of live-weight gain was similar in both groups of sheep.

3. The results confirm those of a previous indoor experiment and show that timothy supplies insufficient sodium to maintain the normal saliva composition of sheep.
\end{abstract}

Work at the Welsh Plant Breeding Station has shown that some grasses are characteristically low in sodium, particularly low levels occurring in timothy. In a previous experiment (Jones, Miles \& Sinclair, r967) feeding a low-sodium timothy hay to housed sheep caused a marked fall in the sodium content of the saliva and an increase in potassium content. The experimental conditions did not permit a meaningful determination of weight gain, but at the end of the 6-week feeding period there were no obvious effects on the well-being of the sheep. As, however, a prolonged period of grazing a low-sodium pasture is more relevant to current farming practice a further trial was designed to compare the effects on weight gain, blood and saliva composition in sheep grazing swards of timothy and ryegrass. The opportunity was also taken to examine the immediate changes in blood and saliva composition at the time of the removal of housed sheep to pasture.

\section{MATERIALS AND METHODS}

Twenty yearling Clun wethers with an average weight of $34 \mathrm{~kg}$ were taken indoors and fed on hay for a period of 2 weeks. On 26 April 1966 the wethers were divided at random into two groups of ten, one group being placed on ryegrass pasture and the other on a $\mathrm{S}_{4} 8$ timothy pasture. The sheep were weighed weekly before turning out to grass and subsequently twice weekly until the experiment terminated on 20 July. Samples of jugular blood and mixed saliva were obtained at $09 \cdot 30 \mathrm{~h}$ on the same day each week and determinations made of sodium and potassium in saliva, sodium, potassium, magnesium and calcium in plasma, and inorganic phosphorus and packed cell volume in whole blood. The sampling and analytical techniques have previously been described by Jones et al. (1967). 
The experiment was conducted on two 3 -acre paddocks. The timothy paddock was a ley established the previous year which had been treated in early March with ${ }^{\cdot} \cdot 5 \mathrm{cwt} /$ acre of compound fertilizer containing $15 \% \mathrm{~N},{ }_{5} \% \mathrm{P}_{2} \mathrm{O}_{5}, 21 \% \mathrm{~K}_{2} \mathrm{O}$. The ryegrass paddock was a perennial ryegrass-dominant permanent pasture which had not been fertilized. When the sheep were first introduced to the paddocks there was a good growth on both swards, but after 3 months of continuous grazing it was apparent that the amount of food available was becoming limiting. The pastures were sampled at intervals of approximately I month, and the chemical composition together with that of the hay offered before turning out is shown in Table 1 . Analysis of the mains water which was available ad lib. showed it to contain $18 \mathrm{mg}$ sodium/l. Analysis of variance was carried out for each sampling date and least significant differences between group means, or mean values with standard errors are shown in the Tables.

\section{RESULTS}

\section{Pasture}

Table I shows that the in vitro digestible organic matter of the timothy tended to be higher than that of the ryegrass, but both decreased as the experiment progressed. With the exception of the first samples, there was little difference in the nitrogen

Table I. Digestible organic matter content and chemical composition of hay and pasture sampled at different times (\% in herbage dry matter)

\begin{tabular}{|c|c|c|c|c|c|c|c|c|c|}
\hline \multirow{2}{*}{\multicolumn{2}{|c|}{ Hay }} & \multicolumn{2}{|c|}{ 2o. iv. 66} & \multicolumn{2}{|c|}{ 26. v. 66} & \multicolumn{2}{|c|}{ 28. vi. 66} & \multicolumn{2}{|c|}{ 20. vii. 66} \\
\hline & & Ryegrass & Timothy & Ryegrass & Timothy & Ryegrass & Timothy & Ryegrass & Timothy \\
\hline DOM* & 53 & 72 & 76 & 67 & 69 & 63 & 69 & $6 I$ & 62 \\
\hline $\mathbf{N}$ & $\mathrm{I} \cdot 55$ & $4 \cdot 23$ & $3 \cdot 22$ & $2 \cdot 14$ & 2.07 & $2 \cdot 50$ & $2 \cdot 46$ & $2 \cdot 36$ & 2.45 \\
\hline $\mathrm{Na}$ & 0.39 & 0.13 & 0.14 & 0.17 & 0.08 & 0.18 & 0.08 & 0.16 & 0.04 \\
\hline $\mathrm{K}$ & $2 \cdot 25$ & $3 \cdot 85$ & $2 \cdot 65$ & 3.70 & $2 \cdot 90$ & $3 \cdot 35$ & $3 \cdot 45$ & $3 \cdot 35$ & $3 \cdot 15$ \\
\hline $\mathrm{Ca}$ & 0.62 & 0.48 & 0.25 & 0.58 & 0.29 & 0.48 & 0.33 & 0.49 & 0.43 \\
\hline $\mathrm{Mg}$ & 0.18 & 0.15 & 0.14 & 0.17 & 0.10 & 0.15 & 0.11 & 0.15 & $0.1 \mathrm{I}$ \\
\hline $\mathbf{P}$ & 0.19 & 0.50 & 0.37 & 0.42 & 0.33 & 0.33 & 0.31 & 0.39 & 0.32 \\
\hline $\mathrm{Cl}$ & $I \cdot 29$ & 0.97 & 0.50 & I. 65 & 0.68 & $I \cdot 33$ & 0.72 & $I \cdot 22$ & 0.72 \\
\hline
\end{tabular}

content, but timothy contained appreciably less calcium, magnesium, phosphorus and chlorine at all sampling dates and less potassium in the earlier samples. In the sample taken on 20 April, almost a week before the sheep were turned out, there was no significant difference in the sodium content of the ryegrass and timothy. By the time of the next sample, however, the sodium content of the timothy had fallen to $0.08 \%$, and it remained at or below this figure until the end of the experiment. On the other hand, the sodium content of the ryegrass tended to rise, from $0.14 \%$ to $0.18 \%$. In a recent report of the Agricultural Research Council (1965) the nutrient requirements of sheep gaining weight at various rates were stated and it is apparent that, with normal intakes of herbage, the timothy pasture would provide inadequate amounts of calcium and sodium. By the same standards, the ryegrass pasture would be considered adequate. The hay given during the preliminary period was also ade- 
quate in most respects, although low in phosphorus and appreciably lower in digestible organic matter and nitrogen than the pastures.

\section{Saliva}

Table 2 shows that within I week of turning the sheep on to the timothy pasture the sodium content of saliva fell and that of potassium increased, giving a fall in the sodium:potassium ratio from $19 \cdot 4: \mathrm{I}$ to $6 \cdot 8: \mathrm{I}$. These trends continued to the end

Table 2. Mean sodium and potassium concentration (m-equiv./l.) in saliva of sheep during indoor feeding and during grazing on timothy or ryegrass pasture

(Each figure represents the mean value for ten sheep)

\begin{tabular}{|c|c|c|c|c|c|c|c|c|c|c|c|c|c|}
\hline & \multirow[b]{2}{*}{ Group } & \multicolumn{2}{|c|}{$\begin{array}{c}\text { Weeks } \\
\text { indoor feeding }\end{array}$} & \multicolumn{9}{|c|}{ Weeks at pasture } & \multirow[b]{2}{*}{ Io } \\
\hline & & I & 2 & I & 2 & 3 & \multirow{2}{*}{$\begin{array}{c}4 \\
16.7 \\
60.0\end{array}$} & \multirow{2}{*}{$\begin{array}{c}5 \\
103 \cdot 7 \\
151 \cdot 9\end{array}$} & \multirow{2}{*}{$\begin{array}{c}6 \\
117 \cdot 0 \\
148 \cdot 0\end{array}$} & \multirow{2}{*}{$\begin{array}{c}7 \\
109 \cdot 7 \\
138.9\end{array}$} & \multirow{2}{*}{$\begin{array}{c}8 \\
104.7 \\
138.9\end{array}$} & \multirow{2}{*}{$\begin{array}{c}9 \\
76 \cdot 6 \\
\text { × } 13.9\end{array}$} & \\
\hline $\mathrm{Na}$ & $\begin{array}{l}\text { Timothy } \\
\text { Ryegrass }\end{array}$ & $\begin{array}{l}\text { I } 73 \cdot 6 \\
167 \cdot 3\end{array}$ & $\begin{array}{l}151.5 \\
150.4\end{array}$ & $\begin{array}{l}\text { I } 57.4 \\
\text { I } 69.6\end{array}$ & $\begin{array}{l}129 \cdot 5 \\
\text { I } 43.5\end{array}$ & $\begin{array}{l}126 \cdot 4 \\
152 \cdot 4\end{array}$ & & & & & & & $\begin{array}{r}97 \cdot 3 \\
126 \cdot 1\end{array}$ \\
\hline \multicolumn{14}{|c|}{ Least significant difference } \\
\hline & $\begin{array}{l}(P=0.05) \\
(P=0.01)\end{array}$ & $\left\{\begin{array}{l}15 \cdot 3 \\
21 \cdot 0\end{array}\right.$ & $\begin{array}{r}9.5 \\
13.0\end{array}$ & $\begin{array}{l}19 \cdot 0 \\
26 \cdot 1\end{array}$ & $\begin{array}{l}13.0 \\
17.8\end{array}$ & $\begin{array}{l}6 \cdot 0 \\
8 \cdot 3\end{array}$ & $\begin{array}{l}17 \cdot 9 \\
24 \cdot 6\end{array}$ & $\begin{array}{l}16 \cdot 8 \\
22 \cdot 9\end{array}$ & $\begin{array}{l}21 \cdot 2 \\
29 \cdot 0\end{array}$ & $\begin{array}{l}14.6 \\
20.5\end{array}$ & $\begin{array}{l}16 \cdot 3 \\
22 \cdot 4\end{array}$ & $\begin{array}{l}13.6 \\
18.7\end{array}$ & $\begin{array}{l}22 \cdot 1 \\
30 \cdot 3\end{array}$ \\
\hline $\mathrm{K}$ & $\begin{array}{l}\text { Timothy } \\
\text { Ryegrass }\end{array}$ & $\begin{array}{l}\text { I } 2.7 \\
\text { I } 3.8\end{array}$ & $\begin{array}{l}7 \cdot 8 \\
8 \cdot 0\end{array}$ & $\begin{array}{r}\text { I I.4 } \\
8 \cdot 9\end{array}$ & $\begin{array}{r}19 \cdot 1 \\
7 \cdot 8\end{array}$ & $\begin{array}{r}25 \cdot 9 \\
9 \cdot 4\end{array}$ & $\begin{array}{l}43.8 \\
10.0\end{array}$ & $\begin{array}{l}50 \cdot 6 \\
12 \cdot 2\end{array}$ & $\begin{array}{l}43 \cdot 3 \\
11 \cdot 5\end{array}$ & $\begin{array}{l}4 I \cdot I \\
I I \cdot 7\end{array}$ & $\begin{array}{l}52 \cdot 6 \\
17 \cdot 2\end{array}$ & $\begin{array}{l}62 \cdot 8 \\
20 \cdot 3\end{array}$ & $\begin{array}{l}50 \cdot 9 \\
20 \cdot 7\end{array}$ \\
\hline \multicolumn{14}{|c|}{ Least significant difference } \\
\hline & $\begin{array}{l}(P=0.05) \\
(P=0.01)\end{array}$ & $\begin{array}{l}6 \cdot 3 \\
8 \cdot 7\end{array}$ & $\begin{array}{l}0.7 \\
1.0\end{array}$ & $\begin{array}{l}4 \cdot 0 \\
5.5\end{array}$ & $\begin{array}{l}5 \cdot 4 \\
7 \cdot 4\end{array}$ & $\begin{array}{l}6 \cdot 1 \\
8 \cdot 3\end{array}$ & $\begin{array}{l}11 \cdot 8 \\
16 \cdot 2\end{array}$ & $\begin{array}{r}9 \cdot 8 \\
\times 3.4\end{array}$ & $\begin{array}{r}8 \cdot 2 \\
11 \cdot 3\end{array}$ & $\begin{array}{l}10.5 \\
14.4\end{array}$ & $\begin{array}{l}13.6 \\
18.7\end{array}$ & $\begin{array}{l}11 \cdot 9 \\
16 \cdot 3\end{array}$ & $\begin{array}{l}17 \cdot 2 \\
23 \cdot 6\end{array}$ \\
\hline
\end{tabular}

of the experiment, when the sodium:potassium ratio was $I \cdot 9: I$. The salivary sodium and potassium contents of the sheep grazing the ryegrass pasture remained within normal limits until the last month of the experiment, when a marked fall in sodium occurred, accompanied by a rise in potassium. The latter change may have been associated with a shortage of available food. At all sampling dates during grazing, except the first, there was a significant between-group difference in saliva sodium and potassium contents.

\section{Blood}

The mean values of the constituents determined in plasma and blood during the period of housing and grazing are shown in Table 3. There was little change in the levels when the sheep were turned out, except for a transient fall in the inorganic phosphorus content of blood. Analysis of variance of the results obtained during the period of grazing showed no significant difference between the groups or between the individual sheep in any of the constituents examined. On the other hand, the differences between the sampling dates were significant $(P<0.00 \mathrm{I})$ for sodium, potassium, magnesium, inorganic phosphorus and packed cell volume. The mean values for these constituents showed no consistent trend over the grazing period except for a rise in the packed cell volume. The significant differences noted were therefore attributable to minor fluctuations between individual sampling dates. 


\section{Live weight}

Despite the changes observed in the saliva composition there appeared to be no adverse effect on the well-being of the sheep and there were no significant betweengroup differences in live-weight gain. Table 4 shows the mean weights of each group when housed and after a grazing period of 4,8 and 12 weeks. The results in the table are the means of two successive weighings in $\mathrm{I}$ week. There was no initial loss of weight during the first few days at pasture and both groups gained weight rapidly for the Ist month; thereafter there was little further increase in weight.

Table 3. Composition of blood and plasma of sheep during indoor feeding and during grazing on timothy or ryegrass pasture

\begin{tabular}{|c|c|c|c|}
\hline & & & \\
\hline & Indoors* & Timothy group & Ryegrass group \\
\hline & & Blood & \\
\hline Packed cell volume (\%) & $27 \cdot 20 \pm 0.46$ & $29 \cdot 40 \pm 0.45$ & $28.90 \pm 0.39$ \\
\hline Inorganic $\mathrm{P}(\mathrm{mg} / \mathrm{l} 00 \mathrm{ml})$ & $5 \cdot 19 \pm 0 \cdot 12$ & $4.54 \pm 0.1$ I & $4.8 I \pm 0.09$ \\
\hline & & Plasma & \\
\hline $\mathrm{Na}$ (m-equiv./1.) & $148 \cdot 30 \pm 1 \cdot 17$ & $144.80 \pm 0.57$ & $146 \cdot 10 \pm 0.43$ \\
\hline $\mathrm{K}$ (m-equiv./1.) & $5.85 \pm 0.09$ & $5.31 \pm 0.05$ & $5 \cdot 3^{8} \pm 0.05$ \\
\hline $\mathrm{Mg}(\mathrm{mg} / \mathrm{ro0} \mathrm{ml})$ & $2 \cdot 04 \pm 0.03$ & $2.33 \pm 0.03$ & $2.28 \pm 0.02$ \\
\hline $\mathrm{Ca}(\mathrm{mg} / \mathrm{I} 00 \mathrm{ml})$ & $8.11 \pm 0.09$ & $8.50 \pm 0.06$ & $8.53 \pm 0.05$ \\
\hline
\end{tabular}

Table 4. Live weight $(\mathrm{kg})$ of sheep during indoor feeding and during grazing on timothy or ryegrass pasture

(Mean values and their standard errors for twenty determinations: ten sheep at two weighing dates)

$\begin{array}{ccccc}\text { Group } & \text { Indoors } & \overbrace{4} & \text { Weeks at pasture } & \text { I2 } \\ \text { Timothy } & 33 \cdot 6 \pm 0.87 & 44 \cdot 2 \pm 0.89 & 45 \cdot 7 \pm 0.91 & 46 \cdot 6 \pm 0.87 \\ \text { Ryegrass } & 35.4 \pm 0.98 & 45 \cdot 0 \pm 1 \cdot 07 & 46 \cdot 3 \pm 0.93 & 46 \cdot 0 \pm I \cdot 00\end{array}$

\section{DISCUSSION}

The most significant result of this experiment was the difference between the saliva composition of sheep grazing a timothy ley and that of sheep grazing a perennial ryegrass-dominant pasture. The outstanding difference in chemical composition of the two herbages was in respect of sodium and chlorine contents. The sodium content of the timothy varied from $0.04 \%$ to $0.08 \%$ for most of the experimental period of I2 weeks, and chlorine varied from $0.50 \%$ to $0.72 \%$. At the end of the experiment the mean saliva sodium level of the timothy group had fallen to $97 \cdot 3 \mathrm{~m}$-equiv./1., and the potassium level had increased to $50.9 \mathrm{~m}$-equiv./1., giving a sodium:potassium ratio of $1 \cdot 9: 1$. Bott, Denton, Goding \& Sabine (1964) quote the normal cation content of ruminant parotid saliva as $160-\mathrm{I} 75 \mathrm{~m}$-equiv. sodium/l., and $4^{-6} \mathrm{~m}$-equiv. potassium/l., with a ratio of $25-40: 1$. The changes in the saliva composition observed in 
the present experiment are similar to those found in a previous study with housed sheep (Jones et al. 1967) when supplementation with sodium was required to prevent the fall in saliva sodium concentration. The results of these experiments, taken together, indicate that timothy given indoors as hay, or grazed, provides an inadequate amount of sodium to prevent changes in the saliva composition. Factors other than sodium intake, however, may influence saliva composition; Dobson, Scott \& Bruce (I966), for example, found that a change in diet was accompanied by a rise in saliva potassium content although the intake of sodium was increased.

In a review of the biological aspects of salivary secretion in ruminants, Blair-West, Bott, Boyd, Coghlan, Denton, Goding, Weller, Wintour \& Wright (1965) have emphasized the role of aldosterone hypersecretion in sodium deficiency and have considered in some detail the mechanism involved. Denton, Goding \& Wright (1959a, b) have pointed out that, under some conditions, the ratio of sodium to potassium in saliva can give an index of aldosterone secretion and can provide a measure of sodium depletion in the sheep. Dobson, Scott \& McDonald (I966) found no correlation between the concentration of sodium and potassium in saliva and blood, a finding supported by the results of the present experiment. It appears therefore that changes in saliva may be more meaningful than those in blood as an indicator of sodium deficiency in the sheep.

There is evidence that sodium supplementation of a low-sodium diet can lead to increased animal productivity. Thus McClymont, Wynne, Briggs \& Franklin (I957) found that sodium supplementation of a high-grain ration containing $0.01-0.06 \%$ sodium improved the live-weight gain of fattening sheep, although in earlier work, Briggs, Franklin \& McClymont (I957) obtained no response in mature dry ewes. More recently, Kemp \& Geurink (I966) have reported an increase in the milk yield of cows given a sodium supplement after a period of 5 months on a low-sodium diet. Devlin \& Roberts ( 1963 ) estimated the sodium requirement of wether lambs weighing between $3^{\circ}$ and $40 \mathrm{~kg}$ to be $\mathrm{I} \cdot \mathrm{OI} \mathrm{g} /$ day, and a similar figure is quoted in the recent report of the Agricultural Research Council (1965). With a dry-matter intake of $\mathrm{I} \mathrm{kg/}$ day this would represent approximately $0.1 \%$ sodium in the diet. Our results show that the $0.04-0.08 \%$ sodium in the timothy pasture was insufficient to prevent marked changes in the saliva composition. Nevertheless, the sheep were able to make weight gains similar to those of sheep grazing a pasture of adequate sodium content. It appears that the ruminant is able to conserve sodium efficiently and the requirement reflects the demands for growth and lactation.

Dobson, Scott \& McDonald (1966) noted a slight fall in plasma magnesium and an increase in saliva potassium in sheep grazing a heavily fertilized pasture of low sodium content, but concluded that sodium deficiency was of minor significance in hypomagnesaemia. In the present experiment there was no significant change in the level of plasma magnesium in the sheep grazing the timothy pasture although the dietary level of both sodium and magnesium fell when the sheep were turned out. Similarly, although the level of calcium in the timothy pasture was low, there was no effect on plasma calcium.

The change in diet which accompanies the turning out of farm animals to pasture 
in the spring is often regarded as a predisposing factor in the occurrence of metabolic disorders. In the present experiment, a change of diet was not reflected in the levels of the blood constituents examined except for a transient fall in inorganic phosphorus. Turning out, however, had a pronounced effect on the saliva composition of the timothy group while no change was noted in the ryegrass group. This finding emphasizes the importance of taking account of the inherent differences in chemical composition of grass species and varieties, an aspect often overlooked in the interpretation of the results of grazing experiments.

\section{REFERENCES}

Agricultural Research Council (1965). The Nutrient Requirements of Farm Livestock. No. 2. Ruminants. London: Agricultural Research Council.

Blair-West, J. R., Bott, E., Boyd, G. W., Coghlan, D. A., Denton, D. A., Goding, J. R., Weller, S., Wintour, M. \& Wright, R. D. (1965). In Physiology of Digestion in the Ruminant, p. 198. [R. W. Dougherty, R. S. Allen, W. Burroughs, N. L. Jacobson and A. D. McGillard, editors.] Washington: Butterworths.

Bott, E., Denton, D. A., Goding, J. R. \& Sabine, J. R. (1964). Nature, Lond. 202, 46 r.

Briggs, P. K., Franklin, M. C. \& McClymont, G. L. (1957). Aust. F. agric. Res. 8, 75.

Denton, D. A., Goding, J. R. \& Wright, R. D. (1959a). Br. med. F. ii, 447.

Denton, D. A., Goding, J. R. \& Wright, R. D. (1959b). Br. med. F. ii, 522.

Devlin, T. J. \& Roberts, W. K. (I963). F. Anim. Sci. 22, 648.

Dobson, A., Scott, D. \& Bruce, J. B. (1966). Q. Fl exp. Physiol. 5I, 3 I I.

Dobson, A., Scott, D. \& McDonald, I. (1966). Res. vet. Sci. 7, 94.

Jones, D. I. H., Miles, D. G. \& Sinclair, K. B. (1967). Br. F. Nutr. 21, 39 I.

Kemp, A. \& Guerink, J. H. (I966). Tijdschr. Diergeneesk. 91, 580.

McClymont, G. L., Wynne, K. N., Briggs, P. K. \& Franklin, M. C., (1957). Aust. F. agric. Res. 8, 83. 